\title{
Gastronomi ve Mutfak Sanatları Öğrencilerinin Gıda Etiketlerini Okuma Düzeyleri
}

DOI: 10.26466/opus.686817

$*$

\author{
Aybuke Ceyhun Sezgin* - Sibel Ayyıldız** - Nur Efşan Durmaz*** \\ Doç. Dr., Ankara Hacı Bayram Veli Üniversitesi Turizm Fakültesi Gastronomi ve Mutfak Sanatları \\ Bölümü, Gölbaşı/Ankara/Türkiye \\ E-Posta: aybuke.ceyhun@hbv.edu.tr \\ ORCID: 0000-0003-1068-9940 \\ Öğr. Gör. Karabük Üniversitesi, Eflani Meslek Yüksekokulu, Aşçllk Bölümü, \\ Eflani/Karabük/Türkiye \\ E-Posta: sibelayyildiz5@gmail.com \\ ORCID: $\underline{0000-0003-0701-2445}$ \\ Araş. Gör. Dr., Ankara Üniversitesi Mühendislik Fakültesi Gıda Mühendisliği Bölümü, \\ Gölbaş1/Ankara/Türkiye \\ E-Posta: nedurmaz@ankara.edu.tr \\ ORCID: 0000-0002-7254-116X
}

\begin{abstract}
Öz
Etiketler, ambalajlanmış gıda ürünü konusunda tüketiciler için önemli bilgiler içermektedir. Günümüzde teknolojik ilerlemeler, ekonomik gelişmeler ve eğitim düzeyinin artması gibi etkenler etiket okuma bilincinde ve duyarlılığında belirgin farklılıklara neden olmuştur. Bu araştırma; gıda bilimi, beslenme ve mutfak uygulamalarına ilişkin çeşitli dersler alan Gastronomi ve Mutfak Sanatları Bölümü öğrencilerinin gıda etiketlerinde yer alan bilgileri okuma düzeylerini belirlemek amactyla planlanmış ve yürütülmüştür. Araştırmaya Ankara Hacı Bayram Veli Üniversitesi, Necmettin Erbakan Üniversitesi ve Nevşehir Hacı Bektaş Veli Üniversitesinde okuyan 392 öğrenci katılmıştır. Öğrencilerin gıda satın alırken fiyat, lezzet, sağlık açısından güvenilirlik ve son tüketim tarihi gibi hususlara dikkat ettikleri belirlenmiş ve fiyatın dikkate alınması öğrenci bütçesi ile ilişkilendirilirken lezzete önem verilmesi öğrencilerin öğrenim gördüğ̈̈̈ alan ile ilişkilendirilmiştir. Öğrenciler tarafindan etiketlerdeki son kullanma tarihi bilgisinin en fazla düzeyde okudunduğu, ürünün brüt miktarn bilgisinin ise en az düzeyde okunduğu belirlenmiştir. Araştırmada kız öğrencilerin etiketlerde helal gıda sertifikasını ve gıdanın alkol içerme durumunu kontrol etme düzeylerinin erkeklere göre daha yüksek olduğu, erkek öğrencilerin ise ürünlerin net miktarı ve brüt miktarın okuma düzeylerinin kız öğrencilere göre daha yüksek olduğu bulunmuştur. Öğrencilerin okudukları alan ile ilgili öğrenim gördükleri süre zarfında aldıkları beslenme ve gıda bilimi derslerinin gıda bileşenler listesi ve gıda güvenliği sistemleri konularında duyarlı davranmalarına katkı sağladığı düşünülmektedir.
\end{abstract}

Anahtar Kelimeler: Etiket, Gıda etiketi, Tüketici davranışı 


\title{
The Levels of Gastronomy and Culinary Arts Students to Read Food Labels
}

\begin{abstract}
The food labels contain important information for consumers about the packaged food products. Today, factors such as technological advances, economical developments, and increasing levels of education have caused significant differences in label reading awareness and liability. This research has been planned and conducted to determine the food label reading level of the Gastronomy and Culinary Arts students who have taken various courses on food science, nutrition, and culinary practices. 392 students from Ankara Hacı Bayram Veli University, Necmettin Erbakan University, and Nevşehir Hacı Bektaş Veli University participated in this research. It was determined that students pay attention to issues such as price, flavor, reliability in terms of health, and expiration date. The consideration of price was associated with the budget of the student while giving importance to flavor was linked to the student's education field. It was determined that the most read information on the label is the expiration date when the least read information was the product gross weight. It was found that female students especially control the halal food certificate and alcohol content more than male students while male students read the net and gross weights more than female students. It is believed that food science and nutrition courses that are taken by the students in the education program are contributing to behave liable to the food ingredients and food safety systems.
\end{abstract}

Keywords: Label, Food label, Consumer behavior 


\section{Giriş}

Toplumlar açısından gıda üretimi ve tüketimi ekonomik, sosyal ve çevresel açıdan büyük önem arz etmektedir. Ülkelerin öncelikli amacı yeterli düzeyde gıda arzını sağlarken, tüketici sağlığının da en iyi şekilde korunmasını temin etmek olmalıdır (Erdoğan, 2014). Tüketici sağlığını korumaya ve yaşam kalitesini artırmaya yönelik eğilimler işletmelerin yeni ürünler geliştirme ve mevcut ürünler üzerinde değişiklik yapma kararların etkilemektedir. Günümüzde tüketicilerin değişen ihtiyaçları ve tercihleri doğrultusunda üreticilerin pazarlama faaliyetlerini gerektiği şekilde yürütebilmesi, rekabet gücü elde etmesi ve yüksek düzeyde tüketici tatmini sağlaması oldukça önemlidir (Aksulu, 2001). Çünkü son yıllarda insanlar daha önce hiç karşılaşmadıkları kadar fazla sayı ve çeşitteki ürün alternatifleri arasından seçim yapmak zorunda kaldıkları gibi ihtiyaçlarını gidermeye yönelik farklı satın alma davranışların da sergilemektedir (Bekar ve Gövce, 2015). Ekonomik gelir düzeylerindeki artış ile beraber tüketiciler, tükettikleri gıdaların besin öğesi içeriğine, güvenilirliğine ve sağlıklı olmasına daha çok önem vermektedir. Bu doğrultuda üreticiler ise kalite kontrol göstergesi olarak ürünlerini sertifikalandırmaya ve etiketlemeye başlamışlardır (Cebeci ve Güneş, 2017). Tüketicilerin gıda etiketlerini okumaları, tüketicilerin korunması, bilgilendirilmesi, sağlıklı ve doğru tercihler yapabilmesi açısından yol gösterici olarak değerlendirilmektedir (Ersoy, Bekar, Yıldızlı, 2012). Bu araştırma ile Gastronomi ve Mutfak Sanatları Bölümünde okuyan öğrencilerin gıda etiketlerinde yer alan bilgileri okuma düzeylerinin belirlenmesi amaçlanmıştır.

\section{Kavramsal Çerçeve}

Etiket, ürüne ait tanımlayıcı bilgiler içeren ve ürünün satın alınması sırasında bu bilgilerin tüketiciye anlaşılır bir biçimde aktarılmasını sağlayan araçtır. Gıda etiketleri ise bir ürünün sahip olduğu porsiyon, kalori ve besin değeri gibi bilgileri içererek ürün hakkında tüketiciye bilgi kazandıran materyallerdir (Cebeci ve Güneş, 2017). Chopera et al. (2014)'e göre gıda etiketi, yasayla bir gıdanın besinsel özelliklerini tüketiciye bildirmeyi amaçlayan bir açıklamadır. Türk Gıda Kodeksi Etiketleme Yönetmeliği'ne göre etiket; gıda ambalajının veya kabının üzerine yazılmış, şablon ile basılmış, işaretlenmiş, kabartma ile işlenmiş, soğuk baskı ile basılmış veya yapıştırılmış olan herhangi 
bir işareti, markayı, damgayı, resimli veya diğer tanımlayıcı unsurlar olarak tanımlanmıştır (Anonim, 2017). Ürünün kimliği olarak bilinen gida etiketleri; gıdanın muhafazası, hazırlanması ve tüketimi hakkında da bilgi aktarmakta (Cop, 2003; FAO, 2019) ve sağllklı beslenmeyi teşvik etmede önemli bir politika aracı olarak değerlendirilmektedir (Lewis et al., 2009; Campos et al., 2011; Hess, Visschers, Siegrist, 2011; Chopera et al., 2014; Kresic and Mrduljas, 2016). Gıda etiketlerinin kullanımı ile sağlıklı diyetler arasında tutarlı bir ilişki olduğunu belirten bilimsel çalışmalar, beslenme etiketlerinin daha sağlıklı beslenmeyi teşvik ettiğine vurgu yapmaktadır (Campos et al., 2011). Azmak ve Sahak (2014)'a göre gıda etiketi, müşteriye mevcut seçenekleri sunmayı, tüketiciyi sağlıklı gıda üretimi ve tüketimine teşvik etmeyi amaçladığı gibi tüketicilerin bir ürünün ortalama değeri hakkında bilinçli bir yargıya varmalarına olanak sağlamaktadır. Ayrıca Falola (2014)'ya göre gıda etiketleri, insanların daha iyi yiyecek satın alma kararı vermelerine ve daha sağlıklı beslenme alışkanlıkları edinmelerine yardımcı olabilmektedir. Gıda etiketlerinin kullanımı, üreticiler ve tüketiciler arasındaki sağlık bilgisi farkını kapatarak, tüketicilerin diyet seçimini de desteklemektedir. Gida etiketinin öncelikli amac1, bir yiyeceğin beslenme kalitesini gerçek ve bilgilendirici olarak tanımlamaktır. Besin içeriği ile ilgili bilgileri etiket üzerinden tüketicilere ileten gıda etiketleri bireylerin günlük öğünlerini planlarken bilinçli yiyecek seçimlerine de yardımcı olmaktadır (Aygen, 2012; Norazmir, Norazlanshah, Naqieyah, Khairil Anuar, 2012).

Üretici firmalar açısından değerlendirildiğinde ise önemli bir pazarlama aracı olarak değerlendirilen etiket, ürünün çekiciliğini artıran grafiklerle ürünün tutundurulmasını kolaylaştırmaktadır (Cop, 2003; Aygen, 2012). Ayrıca üretici ve satıcının satış kontrolü, stok denetimi gibi çalışmalarında çubuk kod uygulaması ile gerek işletme dışı örgütlere, tüketicilere ve rakiplere dönük, gerekse işletme içi oto kontrole yönelik bilgiler vermektedir (Cop, 2003). Etiket bilgileri tüketicilerin ürün hakkında fikir edindiği en önemli bilgi kaynağı olması ayrıca işletmelerin tüketiciye doğru ve yararlı bilgi verebilir nitelikte olması açısından önemlidir. Bu önem tüketicinin sağlığını korumaya katkı sağlarken, yanlış anlamaları önlemeye, gıdayı risklere ve kötü kullanıma karşı korumaya ve işletmeler arası rekabeti düzenleyerek dürüst ticaret yapılmasına ve adil rekabetin oluşmasına katkı sağlamaktadır (Özgül ve Aksulu, 2006; Aygen, 2012). Hayvan refahı, adil ticaret, sürdürülebilir tarım ve izlenebilirlik; gida ürünleri satın alma sürecindeki faktörlerle nispeten daha 
az ilgili iken gıda güvenliği, çevrenin korunması, gıdaların kökeni ve marka itibarı gıda etiketleri için önemli etkenler arasındadır (Bandara, De Silva, Maduwanthi, Warunasinghe, 2016).

Tüketicilerin gıda etiketini okumalarını etkileyen birçok faktör bulunmaktadır (Koç, 2006; Aygen, 2012). Bunların başında etiket okumaya ayrılan zaman, etiketlerin biçimi (boyut, yazı karakterleri, dil) ve tüketicilerin değer yargıları ile genel olarak gıdaların üretimi, dağıtımı ve korunmasına yönelik tutumları gelmektedir (Aygen, 2012). Ollberding et al. (2010) yaş, cinsiyet, eğitim düzeyi, gelir ve hane halkı büyüklügü gibi çeşitli karakteristiklerin gıda etiketini okumayı etkilediğini bildirmiştir. Ürün etiketleri genel olarak marka etiketi, tanımlayıc (bilgi verici) etiket ve derecelendirme etiketi olarak üç sınıfa ayrılmaktadır (Cop, 2003).

\section{Çizelge 1. Etiket Çeşitleri}

\begin{tabular}{ll}
\hline Etiket & Tanımı \\
\hline Marka Etiketi & Mala veya ambalaja uygulanan marka ismidir. \\
\hline \multirow{3}{*}{ Tanımlayıcı Etiketler } & Malın kullanımı, yapısı, bakımı, performansı, boyutu, ağırlı̆̆ı, içeriği \\
& $\begin{array}{l}\text { gibi ürünün kalite standardı veya ölçüleriyle ilgili etiketlerdir. Bu etiket } \\
\text { aynı zamanda ürünün içeriği, imalat ve son kullanım tarihi, fiyatı, üre- } \\
\text { tici firmanın adı ve adresi gibi bilgileri de içermektedir. Ekolojik etiket } \\
\text { ve yeşil nokta tanımlayıcı etiket kapsamındadır. }\end{array}$ \\
\hline Derecelendirme Etiketleri & $\begin{array}{l}\text { Bir ürünün yaklaşık olarak eşit partilere ayrılmasında yararlanılan bir } \\
\text { standart olarak kalite derecesi ya da ölçütünün bir harf, sözcük ya da } \\
\text { sayı ile belirlenerek üzerine yerleştirilmesidir. }\end{array}$ \\
\hline
\end{tabular}

İşlenerek paketlenen gıdaların içerdiği besin bileşenlerine ait bilgilerin etikette gösterilmesi birçok ülkede zorunlu kılınmıştır. Bu zorunluluk ile beslenme etiketleri geniş bir erişime sahip olmakla birlikte satın alma noktasında önemli bir unsur olarak karşımıza çımaktadır (Campos et al., 2011). Avrupa Birliği ülkelerinde ürünlerin serbest dolaşıma konu olması, üye ülkeler arasında rekabet şartlarının dengelenmesini gerekli kılarak etiket konusunda bazı düzenlemeler yapılmasını sağlamıştır. ABD'de 1993 yılında çıkarılan "Besleyicilik ve Etiketleme ve Eğitim" yasasında tüketiciyi etiket aracllı̆̆ıyla bilgilendirme ve eğitim amaçlanmıştır. Bundan yola çıarak etiket üzerinde; ürünün adı, içindekiler listesi, net miktarı, raf ömrü, özel muhafaza ve kullanım koşulları, üreticinin adı ve adresi, menşei, kullanıma ilişkin bilgiler ve \%1.2' den fazla olduğu takdirde alkol içeriği ile ilgili bilgilerin bulunması zo- 
runludur. Besleyicilik değeri ile ilgili bilgilerin (enerji değeri, protein, karbonhidrat, yağ, sodyum, vitamin ve mineral içerikleri) verilmesinin ise zorunlu olmadığı belirtilmiştir (Przyrembel, 2004).

Türkiye'de ise etiketleme ile ilgili düzenlemeler öncelikle 2011 yılında düzenlenen Türk Gıda Kodeksi 28157 sayılı Etiketleme Yönetmeliği ile, son olarak 2017 yılında yayınlanan 29960 sayılı Resmi Gazetedeki değişiklikle son halini almıştır (Anonim, 2017). Türkiye'de etiketleme ile ilgili düzenlemeler bazı farklı yasalarla oluşturulmuştur. Bu yasalardan 1593 sayılı "Umumi Hıfzı Sıhha Kanunu" nun 187. maddesinde, gida ürünlerinin yanlış unvan ve niteliklere ya da halkın aldanmasına yol açacak işaretlerle satışa sunulmasının yasak olduğu belirtilmiştir. Bu kanunun 190. maddesinde ise etiket üzerinde üreten ve pazarlayan firmanın adı, üretim tarihi, nitelikleri, gramajı ve adedine ilişkin bilgilerin bulunmasının zorunlu olduğu iletilmiştir. 4077 sayılı "Tüketiciyi Koruma Kanunu"na ilişkin olarak 2003 yılında çıartılan Etiket Tarife ve Fiyat Listeleri Yönetmeliği'nde etiket üzerinde bulundurulması gereken bilgiler üretim yeri, ürünün ayırıc özelliği ve satış fiyatı şeklinde sıralanmıştır (Özgül ve Aksulu, 2006). Türk Gıda Kodeksi Etiketleme Yönetmeliği'ne göre gıdaların etiketinde yer alması zorunlu olan bilgiler şunlardır (Anonim, 2017).

- Gidanin adi

- Bileşenler listesi

- Alerjiye veya intoleransa neden olan belirli madde veya ürünler

- Belirli bileşenlerin veya bileşen gruplarının miktarı

- Gidanın net miktarı

- Tavsiye edilen tüketim tarihi veya son tüketim tarihi

- Özel muhafaza ve/veya kullanım koşulları

- Gıda işletmecisinin adı veya ticari unvanı ve adresi

- İssletme kayıt numarası veya tanımlama işareti

- Menşe ülke

- Kullanım bilgisi olmadığında gıdanın uygun şekilde tüketimi mümkün değilse, gidanın kullanım talimatı

- Hacmen \%1.2' den fazla alkol içeren içeceklerde hacmen gerçek alkol derecesi

- Beslenme bildirimi'dir. 
Etiketlerin tüketiciler tarafından okunmasına ilişkin literatür incelendiğinde; değişik görüşlere ve bakış açllarına rastlanılmıştır. Tüketicilerin beslenme etiketlerini oldukça güvenilir bir bilgi kaynağı olarak algıladıkları ve bir çok tüketicinin gıda ürünlerini seçmelerine rehberlik etmek için beslenme etiketlerini kullandıkları bildirilmektedir. Etiket okuma seviyesi özellikle sağlık problemleri olan ve özel beslenme gereksinimleri olan bireyler arasında daha yüksek düzeydedir (Campos et al., 2011; Aygen, 2012). Çocuklar, ergenler, yaşlılar, daha az eğitim ve beslenme bilgisine sahip kişiler, geliri düşük olan bireyler ve sınırlı düzeyde sağlık bilincine sahip kişilerin, etiketleri kullanma ve sunulan beslenme bilgilerini etkili bir şekilde işleme koyma olasıllğının düşük düzeyde olduğu belirlenmiştir (Christoph, An, Ellison, 2015). Ollberding et al. (2010) orta ve üst düzey gelire sahip tüketicilerin büyük bir kısmının ürün etiketlerini her zaman okuduklarını ifade etmiştir. Campos et al. (2011) yaptıkları çalışmada yüksek gelire sahip insanların etiket okuma alışkanlığı ve beslenme bilgi düzeylerinin daha yüksek olduğunu belirtmişlerdir. Ayrıca ABD'deki yetişkinlerin \%45-80'inin gıda etiketlerini okuduğunu bildirerek bu uygulama gelişmiş beslenme düzeni ile ilişkilendirilmiştir (Ollberding et al., 2010).

Tüketicilerin gıda etiketlerine karşı olumlu tutumlar sergilediğini destekleyen çalışmalar olsa da tersi durumların olduğu yani hizmet boyutları ve sağlık iddialarının yanıltıcı olduğuna ve etiketlerin yasalara uygunluğuna şüpheli yaklaşan tüketiciler de bulunmaktadır (Campos et al., 2011). Hess et al. (2011) insanların çoğu zaman aynı ürünleri satın aldığını ve bu nedenle aldıkları ürünleri çok iyi tanıdıkları için etiket okumayı gereksiz bir iş olarak gördüklerini bildirmiştir. Ayrıca sağlıklı beslenme konusunda bilinçli tüketiciler, satın alma sırasında gıda etiketlerini incelemeyi düşünmeyebilir, çünkü satın aldıkları gıdanın besin değeri hakkında yeteri kadar zaten bilgiye sahiptirler. Her ne kadar beslenme etiketleri tüketicinin karar vermesini kolaylaştırsa da, çoğu tüketici gıda etiketlerini ya hiç kullanmamakta ya da etiket bilgilerini yeterli düzeyde değerlendirememektedir. Tüketicilerin gida etiketlerini okumama nedenleri arasında okuma işleminin çok fazla zaman alması, beslenme konusuna ilgi duymama, etiket okumanın yararlı olduğunu düşünmeme, aynı ürünler satın alındığı için yapılan seçimin sağlıklı olduğunu düşünme yer almaktadır. Ayrıca etiketteki yazıların küçük olması ve görsellerin yetersiz kalması, tanımlamaların anlaşılamaması, aranan bilgilerin yer- 
lerinin bulunmaması gibi karşılaşılan güçlükler tüketicilerin etiket okumadaki önemli sorunları arasındandır (Aygen, 2012; Karakuş, Küçükkömürler, Ceyhun-Sezgin, 2016; Miller et al., 2017).

Çalışmada yer alan bazı önemli kavramlar şu şekildedir:

$A L O$ 174: Tüketicinin gida güvenilirliği ile ilgili her türlü ihbar ve şikâyet sırasında ilgili merciye kolay bir şekilde ulaşabilmesi amacıyla oluşturulan bir gıda hattıdır. İletişimin tek merkezden yönlendirilmesi, tüketiciye en kısa zamanda dönüş yapilabilmesi ve sonucun takip edilmesi amaciyla kurulmuştur. Bu süreçte tamamen gıda güvenilirliğinin sağlanmasına yönelik yapılan çalışmalara ülke vatandaşlarının da iştirak etmesi hedeflenmiştir (Anonim, 2019).

HACCP: Gida üretiminde önleyici yaklaşım ilkesine göre geliştirilen bir sistemdir. Amaç tarladan sofraya kadar süreçteki tüm aşamalarda güvenilir ve sağlıklı gıda üretimini sağlayan entegre bir sistem kurmaktır (Artık, Şanlier, Ceyhun-Sezgin, 2019). Sistemin hedefi, gida üretiminde sorunlar ortaya çıkmadan gerekli tedbirleri alarak riski önlemektir (Merdol, 2015). CeyhunSezgin ve Artık (2015)'a göre bu sistem gıda işletmelerinde her aşamada oluşabilecek potansiyel tehlikeleri kontrol altına almayı, oluşabilecek tehlikelerin tümü için gerekli önleyici ve düzeltici faaliyetleri sistematik bir biçimde planlamayı, olası fiziksel, kimyasal ve mikrobiyolojik kaynaklı hastalık risklerini en aza indirmeyi amaçlayan bir sistemdir.

GMP (İyi Üretim Uygulamaları): İstenilen kalitede bir gida üretimi için gerekli ilkeleri, uygulamaları ve araçları içeren bir sistemdir. Gıdaların güvenliği ve fonksiyonelliğini garanti altına alan uygulama standartları olarak tanımlanabilen GMP ürünlerde kalite sağlamak için hammadde, işleme, ürün geliştirme, üretim, paketleme, depolama ve dağıtım aşamalarında kesintisiz uygulanması gereken bir teknikler dizisidir (Gülse-Bal, Göktolga, Karkacier, 2006). GMP tarımsal üretimin çevre, insan ve hayvan sağlığına zarar vermeyecek şekilde kontrol altına alınması ve üretim sonucunda oluşan ürünlerin sertifikalandırılarak tarımda izlenebilirlik, sürdürebilirlik ile gıda güvenliğini sağlayan üretim modelidir (Gözen, 2010).

GHP (İyi Hijyen Uygulamalarn): Hijyenik gereksinimlerle ilgili olan bu sistem; gıda üretim tesislerinin hijyenik tasarımı ve yapılandırılmasını, temizleme ve dezenfeksiyon yöntemlerini, gıda işlemede pişmemiş gıdaların mikrobiyal kalitesini, her işlem basamağının hijyenik operasyonu ve personel hijyeni gibi uygulamaları içermektedir (Gülse-Bal vd., 2006). 


\section{Araştırmanın Yöntemi}

Literatürde gıda etiketinin okunma ve kullanımına ilişkin yapılan araştırmaların büyük bir kısmında yetişkin popülasyon üzerine odaklanıldığı ve gençlere yönelik sınırlı sayıda araştırma olduğu tespit edilmiştir. Bu nedenle araştırma; genç tüketiciler arasından öğrenimleri süresince gıda bilimi, beslenme ve mutfak uygulamalarına ilişkin çeşitli dersler alan Gastronomi ve Mutfak Sanatları Bölümü öğrencilerinin gida etiketlerindeki bilgileri okuma düzeylerini belirlemek amacıyla yürütülmüştür. Bu araştırmaya 2019 yılında Şubat ve Mayıs ayları arasında Ankara'da bulunan AHBV Üniversitesi, Konya'da bulunan Necmettin Erbakan Üniversitesi ve Nevşehir'de bulunan Hacı Bektaş Veli Üniversitesi Gastronomi ve Mutfak Sanatları Bölümü'nde okuyan 1., 2., 3. ve 4. sınıf öğrencileri katılmıştır.

Araştırmada nicel araştırma yöntemlerinden veri toplama tekniği olan anket uygulaması kullanılmıştır. Daha önce yapılan çalışmalarda geçerliliği ve güvenilirliği kanıtlanarak kullanılmış ölçeklerden (Özgen ve Aksulu, 2006; Bosi, Çamur, Güler, 2007; Ersoy vd., 2012; Aygen, 2012) yararlanılarak hazırlanan anket, araştırmaya katılmaya gönüllü olan kolayda örnekleme yöntemi ile seçilen 410 öğrenciye uygulanmış ve 392 adedinin kullanılabilir özellikte olduğu tespit edilerek araştırmaya dahil edilmiştir. Anket alanında uzman akademisyenlerden görüş alınarak yapılan düzenlemeler sonrasında uygulanmıştır. Örneklem büyüklüğünün belirlenmesinde 10.000'in üzerinde evren büyüklüğünün olması durumunda oran için kullanılan sınırsız evren örnekleme formülünden yararlanılmıştır (Ural ve Kılıç, 2013). Örneklem büyüklüğünün belirlenmesinde; \%5'lik örneklem hatası ve \%95'lik güven seviyesi dikkate alınarak hesaplandığında, çok büyük sayıdaki evren için gerekli olan sayı 384 olarak belirlenmiştir (Büyüköztürk, 2010; Ural ve Kılıç, 2013; Can, 2014). Güven seviyesi açısından araştırmaya katılmaya gönüllü 392 katılımcı sayısı ile yeterli sayıya ulaşılmıştır.

Geçerlilik ve güvenilirlik, bilimsel araştırmalarda veri toplama aracının en önemli niteliklerinden biridir. Veri toplama sürecinde yapılabilecek rastlant1sal ve sistematik hatalar araştırmanın geçerliliği ve güvenilirliğini etkilemektedir (Ural ve Kılıç, 2013). Sosyal Bilimler alanında yapılan araştırmalarda Alfa yöntemi kullanılarak yapılan güvenilirlik analizi sonucu elde edilen Cronbach Alfa değerinin 0.60'ın üzerinde olduğu durumlarda ölçeğin güve- 
nilir olduğu kabul edilmektedir (Kalayc1, 2009). Araştırmada öğrencilere yöneltilen sorulara yapılan güvenilirlik testi sonucuna göre Cronbach alfa katsayı değeri 0.827 'dir.

Araştırma sonucunda elde edilen veriler istatistik paket programında analizleri yapılarak değerlendirilmiştir. Verilerin analizinde mutlak ve yüzde değer, aritmetik ortalama ve standart sapma, t-testi ve One Way Anova testi kullanılmıştır.

\section{Bulgular}

Araştırmaya katılan öğrencilerin demografik bilgileri Tablo 1'de verilmiştir.

Tablo 1. Demografik Bilgiler ( $n=392)$

\begin{tabular}{|c|c|c|c|c|c|}
\hline Cinsiyet & $\mathbf{n}$ & $\%$ & Aylık Ortalama Gelir (TL) & $\mathbf{n}$ & $\%$ \\
\hline Kadın & 238 & 60.7 & $0-250$ & 20 & 5.1 \\
\hline Erkek & 154 & 39.3 & $251-500$ & 126 & 32.1 \\
\hline \multicolumn{3}{|l|}{ Yaş } & $501-750$ & 121 & 30.9 \\
\hline 18 ve $\downarrow$ & 13 & 3.3 & 751-1000 & 73 & 18.6 \\
\hline 19 & 61 & 15.6 & 1001 ve $\uparrow$ & 52 & 13.3 \\
\hline 20 & 93 & 23.7 & \multicolumn{3}{|l|}{ Nerede Kaldığı } \\
\hline 21 & 97 & 24.7 & Ailesinin yanında & 48 & 12.2 \\
\hline 22 ve $\uparrow$ & 128 & 32.7 & Öğrenci evinde & 125 & 31.9 \\
\hline \multicolumn{3}{|c|}{ Okuduğu Sınıf } & Yurtta & 197 & 50.3 \\
\hline 1. sinif & 84 & 21.3 & Yalnız evde & 8 & 2.0 \\
\hline 2. sinif & 90 & 23.0 & *Diğer (belirtiniz) & 14 & 3.6 \\
\hline 3. sinif & 121 & 30.9 & \multicolumn{3}{|c|}{ Beslenme Eğitimi Alma Durumu } \\
\hline \multirow[t]{5}{*}{ 4. sinuf } & 97 & 24.8 & Evet & 231 & 58.9 \\
\hline & & & Hayır & 161 & 41.1 \\
\hline & & & \multicolumn{3}{|c|}{ Gıda Bilimi Eğitimi Alma Durumu } \\
\hline & & & Evet & 270 & 68.9 \\
\hline & & & Hayır & 122 & 31.1 \\
\hline
\end{tabular}

*Diğer (belirtiniz-bir arkadaşı ile ya da akrabaları ile birlikte yaşama)

Araştırmaya katılan öğrencilerin \%60.7'si kadın, \%39.3'ü erkektir. Yaşlarına göre dağılımları incelendiğinde \%3.3'ü 18 yaş ve altı, \%32.7'si ise 22 yaş ve üstüdür. Katılımcıların \%21.3'ünü 1. sinıf öğrencileri oluştururken, \%24.8' ini 4. sınıf öğrencileri oluşturmaktadır. Öğrencilerin \%32.1'inin 251-500 TL, \%18.6'sinın 751-1000 TL ve \%13.3'ünün 1001 TL ve üzeri aylık ortalama gelirlere sahip olduğu ve \%50.3'ünün yurtta, \%31.9'unun arkadaşlarıyla birlikte öğrenci evinde kaldığı tespit edilmiştir. Katılımcıların okudukları bölüm 
ile ilgili alan dersleri alma durumları incelendiğinde; öğrencilerin \%58.9'unun beslenme ve \%68.9'unun gida bilimi dersi aldığı belirlenmiştir (Tablo 1).

Öğrencilerin gıda satın alımı sırasında dikkat ettikleri hususlar Tablo 2' de verilmiştir.

Tablo 2. Öğrencilerin Gıda Satın Almalarına İlişkin Genel Bilgiler (n=392)

\begin{tabular}{|c|c|c|c|c|c|}
\hline Gida Satın Alınan Yer & $\mathbf{n}$ & $\%$ & Tercih Edilen Ambalaj Türü & $\mathbf{n}$ & $\%$ \\
\hline Semt pazarları & 31 & 7.9 & Cam & 244 & 62.2 \\
\hline Market & 354 & 90.3 & Plastik & 65 & 16.6 \\
\hline Köylerden organik ürün & 7 & 1.8 & Kağıt & 59 & 15.1 \\
\hline $\begin{array}{l}\text { Gida Satın Alırken Nelere } \\
\text { Dikkat Edildiği* }\end{array}$ & $\mathbf{n}$ & $\%$ & Çuval & 12 & 3.1 \\
\hline Fiyat & 239 & 60.9 & **Diğer (Belirtiniz) & 12 & 3.1 \\
\hline Sağlık açısından güvenilirlik & 211 & 53.8 & $\begin{array}{l}\text { Gıda Güvenliğine İlişkin } \\
\text { Kavramları Bilme Durumu }\end{array}$ & $\mathbf{n}$ & $\%$ \\
\hline Lezzet & 234 & 59.6 & ALO 174 & 192 & 49.0 \\
\hline Dayanıklılık & 74 & 18.8 & НАССР & 48 & 12.2 \\
\hline Marka & 137 & 34.9 & GMP (İyi Üretim Uygulamaları) & 151 & 38.5 \\
\hline Promosyonlar & 53 & 13.5 & GHP (İyi Hijyen Uygulamaları) & 1 & 0.3 \\
\hline Son tüketim tarihi & 183 & 46.9 & & & \\
\hline Muhafaza koşulları & 41 & 10.4 & & & \\
\hline
\end{tabular}

*Birden fazla seçenek işaretlenmiştir

**Diğer (Belirtiniz-çevre dostu bez torba ve geri dönüşümü olan ambalajlar)

Öğrencilerin büyük bir kısmının gıdayı marketten (\%90.3) satın aldığı, bir kısmının semt pazarlarından (\%7.9) ve çok az sayıda öğrencinin ise organik ürün şeklinde köylerden (\%1.8) gıdayı satın almayı tercih ettiği belirlenmiştir. Öğrencilerin gıda satın alırken sırasıyla fiyat (\%60.9), lezzet (\%59.6) ve sağlık açısından güvenilirlik (\%53.8) konularına dikkat ettiği, gıdanın dayanıklılık özelliğine (\%18.8), promosyonlara (\%13.5) ve muhafaza koşullarına (\%10.4) pek önem vermediği görülmüştür. Alpuğuz vd. (2009) yaptığı çalışmada; üniversite öğrencilerinin gıda satın alırken en çok dikkate aldığı konunun son kullanma tarihi ve marka olduğunu belirlerken, gıda muhafaza koşullarının öğrenciler açısından dikkate değer bir husus olmadığını tespit etmişlerdir. Aygen (2012)'in yaptığı çalışmada; etiket bilgileri içinde en fazla okunan unsurların sırasıyla son kullanma tarihi, üretim tarihi, ürünün adı-markası ve içindekiler olduğu belirlenmiştir. Yaman ve Özgen (2007) ise öğrencilerin yaklaşık \%80'inin gıdaların üretim ve son kullanma tarihlerine, \%54.1'inin markaya, \%87.2'sinin fiyata dikkat ettiklerini belirlemiştir. 
Öğrencilerin gıda satın alma sırasında ürün ambalajı olarak en fazla cam ambalajı tercih ettiği belirlenirken, \%3.1'lik kısmının çevre dostu bez torba ve geri dönüşümü olan ambalajı tercih ettiği tespit edilmiştir. Etiketlerde yer alan gıda güvenliğine ilişkin kavramlardan en fazla ALO 174, sonra GMP (İyi Üretim Uygulamaları) kavramlarının bilindiği, GHP (İyi Hijyen Uygulamaları) kavramının ise neredeyse hiç bilinmediği belirlenmiştir.

Araştırma kapsamında Gastronomi ve Mutfak Bölümü öğrencilerine gıda etiketlerinde yer alan bilgilerin okunma durumu sorulmuş ve elde edilen veriler Tablo 3'de verilmiştir.

Tablo 3. Öğrencilerin Gıda Etiketlerindeki Bilgileri Okuma Dïzeyleri (n=392)

\begin{tabular}{|c|c|c|c|c|c|c|}
\hline \multirow[t]{2}{*}{$\begin{array}{l}\text { Gida Etiketlerinde Yer } \\
\text { Alan Bilgiler }\end{array}$} & 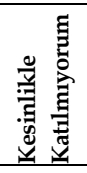 & 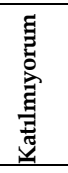 & 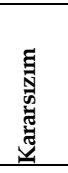 & 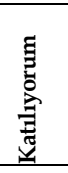 & 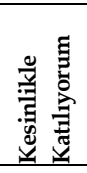 & \multirow[t]{2}{*}{$\overline{\mathrm{X}} \pm \mathrm{ss}$} \\
\hline & $\%$ & $\%$ & $\%$ & $\%$ & $\%$ & \\
\hline İçindekiler listesini okurum & 4.3 & 11.5 & 18.1 & 50.8 & 15.3 & $3.44 \pm 1.32$ \\
\hline Gıda bileşenlerine bakarım & 6.9 & 24.7 & 30.9 & 27.3 & 10.2 & $3.09 \pm 1.09$ \\
\hline $\begin{array}{l}\text { Son kullanma tarihini } \\
\text { kontrol ederim }\end{array}$ & 2.0 & 4.3 & 5.1 & 36.5 & 52.0 & $4.32 \pm 0.90$ \\
\hline Raf ömrüne bakarım & 3.3 & 6.1 & 15.8 & 40.1 & 34.7 & $3.96 \pm 1.02$ \\
\hline Net miktarına bakarım & 6.4 & 20.7 & 25.3 & 31.1 & 16.6 & $3.30 \pm 1.15$ \\
\hline Brüt miktarına bakarım & 7.1 & 22.4 & 34.9 & 24.5 & 11.0 & $3.09 \pm 1.08$ \\
\hline $\begin{array}{l}\text { Gıda katkı maddeleri } \\
\text { içeriğini kontrol ederim }\end{array}$ & 5.1 & 16.3 & 27.8 & 40.3 & 10.5 & $3.34 \pm 1.03$ \\
\hline $\begin{array}{l}\text { Kullanım talimatın dikkate } \\
\text { alırım }\end{array}$ & 2.6 & 4.8 & 13.0 & 56.1 & 23.5 & $3.93 \pm 0.88$ \\
\hline $\begin{array}{l}\text { Hazırlama talimatına } \\
\text { bakarım }\end{array}$ & 2.0 & 5.1 & 10.5 & 56.9 & 25.5 & $3.98 \pm 0.86$ \\
\hline $\begin{array}{l}\text { Muhafaza koşullarına } \\
\text { bakarım }\end{array}$ & 1.0 & 6.9 & 13.3 & 53.8 & 25.0 & $3.94 \pm 0.86$ \\
\hline $\begin{array}{l}\text { Gida güvence sistemlerini } \\
\text { (ISO 22000, HACCP) kontrol } \\
\text { ederim }\end{array}$ & 5.9 & 18.1 & 29.6 & 34.4 & 12.0 & $3.28 \pm 1.07$ \\
\hline $\begin{array}{l}\text { Helal gıda sertifikasını } \\
\text { kontrol ederim }\end{array}$ & 10.2 & 13.5 & 16.8 & 39.8 & 19.6 & $3.45 \pm 1.23$ \\
\hline $\begin{array}{l}\text { Alkol içerme durumuna } \\
\text { bakarım }\end{array}$ & 12.0 & 14.3 & 16.1 & 32.9 & 24.7 & $3.44 \pm 1.32$ \\
\hline $\begin{array}{l}\text { Gida, Tarım ve Hayvancılık } \\
\text { Bakanlığı üretim iznine } \\
\text { bakarım }\end{array}$ & 5.1 & 15.6 & 25.8 & 38.5 & 15.1 & $3.42+1.07$ \\
\hline
\end{tabular}


Öğrencilerin gıda etiketlerindeki ürünün son kullanma tarihi bilgisini en fazla düzeyde $(\bar{x}=4.32 \pm 0.90)$ okudukları belirlenmiştir. Bu durum öğrencilerin büyük bir çoğunluğunun etiketin son kullanma tarihini kontrol etme bilincinde olduklarını göstermektedir. Ayrıca öğrencilerin etiketlerdeki gıda hazırlama talimatı ( $\bar{x}=3.98 \pm 0.86)$ ile raf ömrünü ( $\bar{x}=3.96 \pm 1.02)$ okuma düzeyleri yüksek bulunmuştur. Konu ile ilgili alan derslerinde gıdanın raf ömrünün gıda kaynaklı hastalık ve zehirlenme vakalarında etkili olduğunun vurgulanması bu bilginin öğrenciler tarafından önemsendiğini göstermektedir. Gün ve Orhan (2011)'ın yaptı̆g çalışmada da tüketicilerin satın aldıkları ürünün etiketinde bulunan bilgilerden üretim ve son kullanma tarihine mutlaka bakıldığı belirlenmiştir. Araştırmaya katılan öğrencilerin öğrenim gördükleri alan nedeniyle gıdanın hazırlanma talimatlarını merak ederek önemsedikleri varsayılmaktadır. Öğrencilerin gıda etiket bilgilerinden ISO 22000 ve

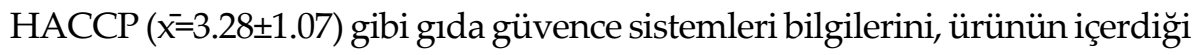
gıda bileşenlerini $(\bar{x}=3.09 \pm 1.09)$ ve gıdanın brüt miktarını $(\bar{x}=3.09 \pm 1.08)$ düşük düzeyde okudukları tespit edilmiştir (Tablo 3).

Tablo 4. Öğrencilerin Gıda Etiketlerindeki Bilgileri Okuma Düzeyinin Cinsiyete Göre Karşılaştırılması ( $n=392)$

\begin{tabular}{llccccc}
\hline Gida Etiketlerinde Yer Alan Bilgiler & Cinsiyet & $\mathbf{n}$ & $\overline{\mathbf{X}}$ & $\mathbf{s s}$ & $\mathbf{t}$ & $\mathbf{p}$ \\
\hline İçindekiler listesini okurum & Kadın & 238 & 3.65 & 1.21 & \multirow{2}{*}{3.925} & $0.000^{*}$ \\
\multirow{2}{*}{ Net miktarına bakarım } & Erkek & 154 & 3.11 & 1.42 & & \\
& Kadın & 238 & 3.21 & 1.12 & -2.011 & $0.045^{*}$ \\
\multirow{2}{*}{ Brüt miktarına bakarım } & Erkek & 154 & 3.45 & 1.20 & & \\
& Kadın & 238 & 2.99 & 1.08 & \multirow{2}{*}{0.2 .297} & $0.022^{*}$ \\
\multirow{2}{*}{ Helal gıda sertifikasını kontrol ederim } & Erkek & 154 & 3.25 & 1.08 & & \multirow{2}{*}{$0.000^{*}$} \\
& Kadın & 238 & 3.64 & 1.11 & \multirow{2}{*}{3.879} & \\
\multirow{2}{*}{ Alkol içerme durumuna bakarım } & Erkek & 154 & 3.15 & 1.35 & & \multirow{2}{*}{$0.000^{*}$} \\
\hline
\end{tabular}

${ }^{*} \mathrm{p}<0.05$

Gıda etiket bilgilerinin öğrenciler tarafından okunma düzeyinin cinsiyete göre karşılaştırılması sonucunda; istatistiki açıdan anlamlı fark olduğu tespit edilen etiket bilgileri Tablo 4' de verilmiştir. Etikette bulunan bilgilerden "içindekiler listesini okurum" ifadesine verilen cevapların ortalamalarının kız öğrencilerde ( $\bar{x}=3.65 \pm 1.21)$ erkek öğrencilere $(\bar{x}=3.11 \pm 1.42)$ göre daha yüksek olduğu belirlenmiştir. Aygen (2012)'nin yaptığı çalışmada kız öğrencilerin erkek öğrencilere göre etiket bilgilerini daha fazla okudukları belirlenmiştir. 
Her iki cinsiyeti de içeren çalışmaların çoğunda kızların erkeklerden daha fazla gıda etiket bilgilerini okuduğu saptanmıştır (Christoph et al., 2015). Aynı zamanda kadın tüketiciler etiketlerin gıda seçimlerini etkilediğini ve gıda etiketlerine güvendiklerini bildirmiştir (Furlow and Knott, 2003; Campos, Doxey, Hammond, 2011). Nijerya'da yapılan bir çalışmada ise kadınların gıda etiketlerini erkeklerden daha fazla okumaya istekli olduğu vurgulanmıştır (Falola, 2014). Araştırmada ayrıca kız öğrencilerin etiketlerde helal gıda sertifikasını $(\bar{x}=3.64 \pm 1.11)$ ve gıdanın alkol içerme durumunu $(\bar{x}=3.35 \pm 1.21)$ kontrol etme düzeyinin erkeklere göre daha yüksek olduğu, erkek öğrencilerin ise ürünlerin net miktarı $(\bar{x}=3.45 \pm 1.20)$ ve brüt miktarını ( $\bar{x}=3.25 \pm 1.08$ ) okuma düzeylerinin kız öğrencilere göre daha yüksek olduğu bulunmuştur.(Tablo 4).

Tablo 5. Öğrencilerin Gıda Etiketlerindeki Bilgileri Okuma Düzeyinin Öğrenim Gördükleri Sınıfa Göre Karşılaştırılması ( $n=392)$

\begin{tabular}{|c|c|c|c|c|c|c|}
\hline Gıda Etiketlerinde Yer Alan Bilgiler & Sinif & $\mathbf{n}$ & $X$ & ss & $\mathbf{F}$ & $\mathbf{p}$ \\
\hline \multirow{4}{*}{ Gida bileşenlerine bakarım } & 1 & 84 & 2.85 & 1.09 & \multirow{4}{*}{$\begin{array}{l}5.050 \\
(1.2 .3-4)\end{array}$} & \multirow{4}{*}{$0.002^{*}$} \\
\hline & 2 & 90 & 3.01 & 1.05 & & \\
\hline & 3 & 121 & 3.03 & 1.12 & & \\
\hline & 4 & 97 & 3.44 & 1.02 & & \\
\hline \multirow{4}{*}{$\begin{array}{l}\text { Gida güvence sistemlerini (ISO 22000, } \\
\text { HACCP) kontrol ederim }\end{array}$} & 1 & 84 & 3.05 & 1.07 & \multirow{4}{*}{$\begin{array}{l}3.056 \\
(1-4)\end{array}$} & \multirow{4}{*}{$0.028^{*}$} \\
\hline & 2 & 90 & 3.32 & 1.13 & & \\
\hline & 3 & 121 & 3.22 & 1.11 & & \\
\hline & 4 & 97 & 3.52 & 0.92 & & \\
\hline
\end{tabular}

${ }^{*} \mathrm{p}<0.05$

Araştırma kapsamında gıda etiket bilgilerinin öğrenciler tarafından okunma düzeyinin öğrencilerin öğrenim gördükleri sınıfa göre karşılaştırılması sonucunda; istatistiki açıdan anlamlı fark olduğu tespit edilen etiket bilgileri Tablo 5'de verilmiştir. Gıda etiketlerinde yer alan ifadelerden "gıda bileşenlerine bakarım" ifadesinde verilen cevapların ortalamalarının 1. sınıftan $(\bar{x}=2.85 \pm 1.09), 4$. sinıfa $(\bar{x}=3.44 \pm 1.02)$ doğru arttığ görülmektedir. Elde edilen bu sonuçlara göre öğrencilerin alanlarında yıllar itibariyle öğrenim düzeylerindeki artışın satın aldıkları ürünlerin bileşenleri hakkında bilinç düzeyini arttırdığı söylenebilmektedir. Ayrıca etiketlerde üretici firmaların sahip oldukları ISO 22000 ve HACCP gibi gida güvence sistemleri bilgisini kontrol etme durumunun 4. sinıfta okuyan öğrencilerde en yüksek seviyede 
( $\bar{x}=3.52 \pm 0.92)$ olduğu görülmüştür. Alan ile ilgili olarak beslenme ve gıda bilimi derslerinin eğitim sürecinin 2. ve 3. yıllarında verilmesi 4. sınıf öğrencilerinde bu bilgi düzeyinin artışına katkı sağlamıştır (Tablo 5).

Tablo 6. Öğrencilerin Gıda Etiketlerindeki Bilgileri Okuma Düzeyinin Gıda Bilimi Ĕ̆itimi Alma Durumuna Göre Karşılaştırılması (n=392)

\begin{tabular}{|c|c|c|c|c|c|c|}
\hline $\begin{array}{l}\text { Gida Etiketlerinde Yer Alan } \\
\text { Bilgiler }\end{array}$ & Gıda Bilimi Eğitimi Alma & n & $\bar{X}$ & ss & $\mathbf{t}$ & $\mathrm{p}$ \\
\hline \multirow{2}{*}{ İçindekiler listesini okurum } & Evet & 270 & 3.68 & 0.96 & \multirow{2}{*}{2.120} & \multirow{2}{*}{$0.035^{*}$} \\
\hline & Hayır & 122 & 3.44 & 1.10 & & \\
\hline
\end{tabular}

$\mathrm{p}<0.05$

Gıda etiket bilgilerinin öğrenciler tarafından okunma düzeyinin öğrencilerin gıda bilimi eğitimi alma durumuna göre karşılaştırılması sonucunda; istatistiki açıdan anlamlı fark olduğu tespit edilen etiket bilgileri Tablo 6'da verilmiştir. Gıda bilimi eğitimi alan öğrencilerin satın aldıkları ürüne ait içindekiler listesini okuma düzeylerinin yüksek olduğu ( $\bar{x}=3.68 \pm 0.96)$ belirlenmiştir. Öğrencilerin gıda bilimi, gıda bileşenleri ve gıda teknolojisi gibi konuları içeren gıda eğitimi dersini almalarının, satın aldıkları gıdaların bileşimini sorgulamaya katkı sağladığını göstermektedir. Christoph et al. (2015)'e göre gıda eğitimi gıda etiketlerine yönelik tutumları geliştirmekte ancak algıları davranışsal değişime dönüştürmek için daha fazla eğitimsel çabanın gerekli olduğunu vurgulamaktadır.

Tablo 7. Öğrencilerin Gıda Etiketlerindeki Bilgileri Okuma Düzeyinin Beslenme Eğitimi Alma Durumuna Göre Karşılaştırılması (n=392)

\begin{tabular}{|c|c|c|c|c|c|c|}
\hline Gıda Etiketlerinde Yer Alan Bilgiler & $\begin{array}{l}\text { Beslenme } \\
\text { Eğitimi Alma }\end{array}$ & $\mathbf{n}$ & $\overline{\mathbf{x}}$ & ss & $\mathbf{t}$ & $\mathbf{p}$ \\
\hline \multirow{2}{*}{ İçindekiler listesini okurum } & Evet & 231 & 3.76 & 0.95 & \multirow{2}{*}{3.572} & \multirow{2}{*}{$0.000^{*}$} \\
\hline & Hayır & 161 & 3.39 & 1.06 & & \\
\hline \multirow{2}{*}{ Gıda bileşenlerine bakarım } & Evet & 231 & 3.19 & 1.06 & \multirow{2}{*}{2.242} & \multirow{2}{*}{$0.026^{*}$} \\
\hline & Hayır & 161 & 2.94 & 1.12 & & \\
\hline \multirow{2}{*}{$\begin{array}{l}\text { Gida güvence sistemlerini (ISO 22000, } \\
\text { HACCP) kontrol ederim }\end{array}$} & Evet & 231 & 3.38 & 1.05 & \multirow{2}{*}{2.202} & \multirow{2}{*}{$0.028^{*}$} \\
\hline & Hayır & 161 & 3.14 & 1.10 & & \\
\hline \multirow[t]{2}{*}{ Helal gida sertifikasını kontrol ederim } & Evet & 231 & 3.59 & 1.17 & \multirow{2}{*}{2.739} & \multirow{2}{*}{$0.006^{*}$} \\
\hline & Hayır & 161 & 3.24 & 1.29 & & \\
\hline \multirow[t]{2}{*}{ Alkol içerme durumunu kontrol ederim } & Evet & 231 & 3.56 & 1.27 & \multirow{2}{*}{2.159} & \multirow{2}{*}{$0.029^{*}$} \\
\hline & Hayır & 161 & 3.26 & 1.37 & & \\
\hline \multirow{2}{*}{$\begin{array}{l}\text { Gida, Tarım ve Hayvancılık Bakanlığı } \\
\text { üretim iznine bakarım }\end{array}$} & Evet & 231 & 3.51 & 1.06 & \multirow{2}{*}{1.908} & \multirow{2}{*}{$0.057^{*}$} \\
\hline & Hayır & 161 & 3.30 & 1.08 & & \\
\hline
\end{tabular}

${ }^{*} \mathrm{p}<0.05$ 
Araştırma kapsamında gida etiket bilgilerinin öğrenciler tarafından okunma düzeyinin öğrencilerin beslenme eğitimi alma durumuna göre karşılaştırılması sonucunda; istatistiki açıdan anlamlı fark olduğu tespit edilen etiket bilgileri Tablo 7 'de verilmiştir. Beslenme eğitimi alan öğrencilerin içindekiler listesini okuma ( $\bar{x}=3.76 \pm 0.95)$, gida bileşenlerine bakma ( $\bar{x}=3.19 \pm 1.06)$, gida güvence sistemlerini (ISO 22000, HACCP) kontrol etme ( $\bar{x}=3.38 \pm 1.05)$, helal gida sertifikasını kontrol etme ( $\bar{x}=3.59 \pm 1.17)$, gidanın alkol içerme durumunu kontrol etme ( $\bar{x}=3.56 \pm 1.27)$ ve Gida, Tarım ve Hayvancilık Bakanlığ üretim iznini kontrol etme ( $\bar{x}=3.51 \pm 1.06)$ düzeylerinin beslenme eğitimi almayan öğrencilere göre daha yüksek olduğu tespit edilmiştir. Elde edilen veriler doğrultusunda beslenme dersinin öğrencilerin satın aldıkları ürün etiketlerindeki bilgileri okuma düzeylerine ve kontrol etme davranışlarına olumlu yönde etki ettiği söylenebilmektedir. Yapılan bir çalışmada besin etiketindeki bilgileri anlama düzeyinin beslenme bilgisiyle ilişkili olduğu saptanmıştır. Ayrıca bilgi düzeyinin artmasıyla etiket okuma düzeyi arasında pozitif bir ilişki belirlenmiştir (Ranilovic and Baric, 2011).

\section{Sonuç ve Öneriler}

Gastronomi ve Mutfak Sanatları Bölümünde öğrenim gören öğrencilerin gıda etiket bilgilerini okuma düzeylerini belirlemeyi amaçlayan bu araştırmada aşağıdaki sonuçlar elde edilmiştir.

Öğrencilerin büyük bir kısmının marketten alışveriş yaptığı ve gida satın alırken sırasıyla fiyat, lezzet, sağlık açısından güvenilirlik ve son tüketim tarihi gibi konulara dikkat ettikleri tespit edilmiştir. Gıda fiyatının bu kadar ön planda olması öğrenci ekonomisi ile ilişkilendirilirken, lezzete önem verilmesi öğrencilerin öğrenim gördüğü alan ile ilişkilendirilmiştir. Öğrencilerin cam ambalaj tercihlerinin yüksek olduğu, çevre dostu bez torba ve geri dönüşümlü ambalajları tercih düzeylerinin düşük olduğu belirlenmiştir. Gıda güvenliğine ilişkin kavramlardan en fazla ALO 174 hattının bilindiği görülmüştür. Elde edilen veriler öğrencilerin gıda güvenliği konusunda bilinçli bir yaklaşım sergilediklerini göstermektedir.

Öğrencilerin gıda etiketlerinde ürünlerin son kullanma tarihini kontrol etme ve gida hazırlama talimatı bilgilerini okuma düzeyleri yüksektir. Bilindiği üzere gıdaların güvenilir bir şekilde tüketilebileceği süreleri içeren raf ömürleri, gıda kaynaklı zehirlenme vakalarında etkili faktörlerden birisidir. 
Gıdaların son kullanma tarihinin okunma düzeyinin yüksek olması öğrencilerin bu teorik bilgiyi önemsediklerinin göstergesidir. Ayrıca öğrencilerin ürünlerin tüketim öncesi hazırlanma talimatı gibi teknik bilgileri okumalarında öğrenim gördükleri alanın etkisinin olduğu varsayılmaktadır. Kız öğrencilerin erkek öğrencilere göre gıda etiketlerindeki bilgileri daha fazla düzeyde okudukları belirlenmiştir. Bununla birlikte öğrencilerin etiketlerde yer alan gıda bileşenleri listesini ve gıda güvence sistemleri bilgisini kontrol etme durumlarının öğrenim düzeyleri ile paralel olarak arttı̆̆ söylenebilir. Gıda bilimi ve beslenme eğitiminin etiketlerdeki bilgilerin okunma düzeyini artırdığı görülmüştür.

Tüm bu sonuçlar ışığında; öğrencilerin eğitim ile elde ettikleri teorik bilgilerin yaşamsal ve mesleki uygulamalara yansımasının önemli olduğu belirlenmiştir. Öğrenciler aldıkları eğitim sayesinde elde ettikleri teori ve pratik bilgileri diğer insanlarla da paylaşarak, etiket okuma bilincinin oluşturulmasına destek olmalıdırlar. Etiket okuma sürdürülebilirliği ile sağlıklı ve güvenli gıda tercihlerini gerek çalıştıkları alanlarda gerekse diğer yaşamsal alanlarda teşvik edebilecekleri düşünülmektedir. 


\title{
EXTENDED ABSTRACT
}

\section{The Levels of Gastronomy and Culinary Arts Students to Read Food Labels}

\author{
* \\ Aybuke Ceyhun Sezgin - Sibel Ayyıldız - Nur Efşan Durmaz \\ Ankara Hacı Bayramı Veli University, Karabük Üniversity, Ankara University
}

Literature Review: A label is a tool that contains descriptive details about the product and ensures that these details are understandably transferred to the consumer during the purchasing. Food labels, on the other hand, are materials that provide details about the product such as portion, calorie, and nutritional value to the consumers (Cebeci and Güneş, 2017). Food labels known as the identity of the product convey preservation, preparation, and consumption details of food (Cop, 2003; FAO, 2019) and is considered an important policy tool in promoting healthy eating (Lewis et al., 2009; Campos et al., 2011; Hess, Visschers, Siegrist, 2011; Chopera et al., 2014; Kresic and Mrduljas, 2016).

Many factors affect consumers' reading level of the food label (Koç, 2006; Aygen, 2012). The most important of these is the time allocated to reading labels, the format of the label (size, typeface, language), the value judgments of the consumers, and their attitudes towards the production, distribution, and protection of the food in general (Aygen, 2012). Ollberding et al. (2010) reported that various characteristics such as age, gender, education level, income level, and the number of households affect the reading level of the food label.

It was reported that consumers perceive nutrition labels as a highly reliable source of information and many consumers used nutrition labels to guide their food choice. The level of label reading was higher among individuals especially with health problems and special dietary needs (Campos et al., 2011; Aygen, 2012). It was determined that children, adolescents, the elderly, people with low levels of nutritional knowledge, people with low income, and people with limited health awareness did less likely care about the labels 
and did not effectively process the nutritional information provided (Christoph, An, Ellison, 2015). Ollberding et al. (2010) stated that most middle and upper-income consumers always read product labels.

Research Aim: This research was conducted to determine the reading level of the food labels of the students at the Department of Gastronomy and Culinary Arts, who took various courses such as food science, nutrition, and culinary practices in their education. 1st, 2nd, 3rd and 4th-year students studying at Gastronomy and Culinary Arts Departments at AHBV University in Ankara, Necmettin Erbakan University in Konya, and Hacı Bektaş Veli University in Nevşehir participated in this research between February and May 2019.

Research Method: A Questionnaire, which is a data collection technique among quantitative research methods, was used in this study. The questionnaire was prepared using scales studied in previous researches proving its validity and reliability (Özgen and Aksulu, 2006; Bosi, Çamur, Güler, 2007; Ersoy et al., 2012; Aygen, 2012). The questionnaire was given to 410 students who volunteered to participate in using the convenience sampling method and 392 were useable to include in this study. The questionnaire was applied after the arrangements were made by consultation with expert academicians. Findings: It was determined that most of the students bought food from the market $(90.3 \%)$, some of them preferred to buy from the local markets $(7.9 \%)$, and very few students from the villages $(1.8 \%)$ as organic products. It was seen that at purchasing food, students paid attention to price $(60.9 \%)$, taste $(59.6 \%)$, and reliability in terms of health $(53.8 \%)$, but did not pay attention to the durability of food $(18.8 \%)$, promotions $(13.5 \%)$ and storage conditions (10.4\%). It was determined that students mostly preferred glass packaging as product packaging, and $3.1 \%$ of them preferred environmentally friendly cloth bags and recyclable packaging. It was determined that among the concepts related to food safety in the labels, ALO 174 and then GMP (Good Manufacturing Practices) were most known, but the concept of GHP (Good Hygiene Practices) was rarely known.

It was determined that the students read the expiration date of the product on food labels at the highest level $(\bar{x}=4.32 \pm 0.90)$. This means that most of the students are conscious of checking the expiration date of the label. In addition, students' reading levels of food preparation instruction $(\bar{x}=3.98 \pm 0.86)$ and shelf life $(\bar{x}=3.96 \pm 1.02)$ on labels were found to be high. Emphasizing that 
the shelf life of food is a factor in food-borne illness and poisoning in related courses shows that students care about this information.

It is determined that most of the students pay attention to issues such as price, taste, reliability in terms of health, and expiration date to purchase food. Paying attention to the price of food is attached to the student budget, while the emphasis on taste is associated with the study area of the students. Students' level of checking the food ingredients lists and food security systems on labels increases as their education level increases. It is observed that food science and nutrition courses increase the reading level of food labels. According to the data, it is concluded that the nutrition course has a positive effect on the students to read and control the labels while purchasing. In a study, it was determined that the level of understanding the food label details was related to nutritional knowledge. Besides, a positive relationship was found between the level of knowledge and reading labels (Ranilovic and Baric, 2011).

In conclusion, it is determined that the reflection of the theoretical knowledge gained by students through education on daily and professional practices is important. Students should support the creation of label reading awareness by sharing their theoretical and practical information they have acquired through education with other people. It is thought that students may encourage their healthy and safe food choices with the sustainability of label reading at their work and other daily areas.

\section{Kaynakça / References}

Aksulu, İ. (2001). Tüketicide sağlığını koruma bilinci ve satın alma noktasında tüketici tutumları: Ambalajlı gida ürünleri üzerine bir araştırma. Dokuz Eylül Üniversitesi İktisadi ve İdari Bilimler Fakültesi Dergisi, 16, 115-127.

Alpuğuz, G., Erkoç, F., Mutluer, B., Selvi, M. (2009). Gençlerin (14-24 yaş) gida hijyeni ve ambalajlı gıdaların tüketimi konusundaki bilgi ve davranışlarının incelenmesi. Türk Hijyen ve Deneysel Biyoloji Dergisi, 66(3), 107-115.

Anonim, (2019). Alo 124 gida hatt, http://www.alo174.gov.tr/Index.aspx adresinden erişilmiştir.

Artık, N., Şanler, N., ve Ceyhun-Sezgin, A. (2019). Gıda gü̈venliği ve gıda mevzuatı. Genişletilmiş 2. bask1, 544 sayfa, (ISBN No: 978-605- 9440-88-2), Detay Anatolia Akademik Yayıncllık Ltd. Şti., Ankara. 
Aygen, F.G. (2012). Tüketicilerin besin etiketi incelenmesi konusundaki tutum ve davranışları. İşletme Araştırmaları Dergisi, 4(3), 28-54.

Azmak, N., Sahak, S.Z. (2014). Nutritional label and consumer buying decision: A preliminary review. Procedia-Social and Behavioral Sciences, 130, 490-498.

Bandara, B.E.S., De Silva, D.A.M., Maduwanthi, B.C.H., Warunasinghe, W.A.A.I. (2016). Impact of food labeling information on consumer purchasing decision: with special reference to faculty of agricultural sciences. Procedia Food Science, 6, 309-313.

Bekar, A., Gövce, A.M. (2015). Tüketicilerin gıda satın alma davranışları ile yaşam tarzı ilişkisi. Journal of International Social Research, 8(36), 946-958.

Bosi, T.B., Çamur, D., Güler, Ç. (2007). Hacettepe Üniversitesi'nde çalışan bazı personelin gida satın alırken dikkat ettikleri özelliklerin ve gida katkı maddeleri hakkındaki bilgi düzeylerinin saptanması. Beslenme ve Diyet Dergisi, 35(1), 9-16.

Büyüköztürk, Ş. (2010). Bilimsel araştırma yöntemleri. Pegem Akademi Yayıncllk: Ankara.

Campos, S., Doxey, J., Hammond, D. (2011). Nutrition labels on pre-packaged foods: a systematic review. Public Health Nutrition, 14(8), 1496-1506.

Can, A. (2014). SPSS ile bilimsel araştırma süresince nicel veri analizi. Pegem Akademi Yayıncllk: Ankara.

Cebeci, A., Güneş, F.S. (2017). Türkiye ve Avrupa'daki tüketicilerin gida etiketi okuma tutumların etkileyen faktörlerin değerlendirilmesi. Gümüşhane Üniversitesi Sağllk Bilimleri Dergisi, 6(4), 261-267.

Ceyhun-Sezgin, A., Artk, N. (2015). Toplu tüketim yerlerinde gida güvenliği ve HACCP uygulamaları. Journal of Tourism and Gastronomy Studies, 3(2), 56-62.

Chopera, P., Chagwena, D.T., Mushonga, N.G.T. (2014). Food label reading and understanding in parts of rural and urban Zimbabwe. African Health Sciences, 14(3), 576-584.

Christoph, M.J., An, R., Ellison, B. (2015). Correlates of nutrition label use among college students and young adults: A review. Public Health Nutrition, 19(12), 2135-2148.

Cop, R. (2003). Tüketim mallarının ambalajinn ve etiket bilgilerinin tüketici satın alma davranışlarına etkileri ve bir uygulama. Meozuat Dergisi, 6(62), 1-15.

Erdoğan, S. (2014). Bir insan hakları sorunu olarak gıda güvenliği. Hayat Yayın Gurubu, 1347. İstanbul.

Ersoy, A.F., Bekar, A., Yıldızlı, F. (2012). Tüketicilerin gıda ürünü satın almada etiket duyarllığı. 1. Uluslararası Aile ve Tüketici Bilimleri Kongresi, 07-10 Kasım, Antalya. 
Falola, A. (2014). Towards nutrition security: food label use among Nigerians. International Journal of Food and Agricultural Economics, 2(2), 127-134.

FAO. (2019). Food labelling, food and agriculture organization of The United Nations, 13.12.2019 tarihinde .http://www.fao.org/food-labelling/en/ adresinden erişilmiştir.

Furlow, N.E., Knott, C. (2009). Who's reading the label? millennials' use of environmental product labels. The Journal of Applied Business and Economics, 10(3), 1-12.

Gözen, H. (2010). Seracılı üretimi faaliyetlerinde iyi tarım uygulamaları Kıbrıs Magosa örneği. Namik Kemal Üniversitesi Fen Bilimleri Enstitüsü Yüksek Lisans Tezi, 1-95. Tekirdağ.

Gülse-Bal, H.S., Göktolga, Z.G., Karkacier, O. (2006). Gıda güvenliği konusunda tüketici bilincinin incelenmesi: Tokat ili örneği. Tarm Ekonomisi Dergisi, 12(1), 9-18.

Gün, İ., Orhan, H. (2011). Süt ve ürünleri tüketicilerinin etiket bilgi düzeylerinin incelenmesi. Iğdır Üniversitesi Fen Bilimleri Enstitüsü Dergisi, 1(1), 45-51.

Hess, R., Visschers, V.H.M., Siegrist, M. (2011). The role of health-related, motivational and sociodemographic aspects in predicting food label use: A comprehensive study. Public Health Nutrition, 15(3), 407-414.

Kalayc1, Ş. (2009). SPSS applied multivariate statistical techniques. Asil Publishing: Ankara.

Karakuş, S.Ş., Küçükkömürler, S., Ceyhun-Sezgin, A. (2016). Tüketicilerin gıda etiketlerini okuma durumlan ve tercihleri. Sosyal Bilimler Dergisi, 3(6), 321-331.

Koç, B. (2006). Tüketicilerin gıda ürünlerini satın alma davranışları: Adana ili örneği. Türkiye 9. Gıda Kongresi, 24-26 Mayıs 2006, 787-790, Bolu.

Kresic, G., Mrduljas, N. (2016). The relationship between knowledge and the use of nutrition information on food package. Acta Alimentaria, 45(1), 36-44.

Lewis, J.E., Arheart, K.L., LeBlanc, W.G., Fleming, L.E., Lee, D.J., Davila, E.P., CabánMartinez, Clark, J.D. (2009). Food label use and awareness of nutritional information and recommendations among persons with chronic disease. The American Journal of Clinical Nutrition, 90(5), 1351-1357.

Miller, L.M.S., Beckett, L.A., Bergman, J.J., Wilson, M.D., Applegate, E.A., Gibson, T.N. (2017). Developing nutrition label reading skills: a web-based practice approach. Journal of Medical Internet Research, 19(1), 1-12.

Norazmir, M.N., Norazlanshah, H., Naqieyah, N., Khairil Anuar, M.I. (2012). Understanding and use of food package nutrition label among educated young adults. Pakistan Journal of Nutrition, 11(10), 836-842.

Ollberding, N.J., Wolf, R., Contento, I. (2010). Food label use and its relation to dietary intake among US adults. Journal of the American Dietetic Association, 110, 12331237. 
Özgül, E., Aksulu, İ. (2006). Ambalajlı gıda ürünlerinde tüketicilerin etiket duyarlllı̆̆ındaki değişimler. Ege Akademik Bakış Dergisi, 6(1), 1-9.

Przyrembel, H. (2004). Food labelling legislation in the EU and consumers information. Trends in Food Science \& Technology, 15(7-8), 360-365.

Ranilovic, J., Baric, I.C. (2011). Differences between younger and older populations in nutrition label reading habits. British Food Journal, 113(1), 109-121.

Türk Gıda Kodeksi Gıda Etiketleme ve Tüketicileri Bilgilendirme Yönetmeliği (2017). Resmi Gazete., 26 Ocak 2017 tarih ve sayı: 29960 (Mükerrer)

Ural, A., Kilıç, İ. (2013). Bilimsel araştırma süreci ve SPSS ile veri analizi. Detay Yayıncllk: Ankara.

Yaman, M., Özgen, L. (2007). Üniversite öğrencilerinin yurtlarındaki besin hijyeni yaklaşımları ve besin hazırlama uygulamaları. Gazi Üniversitesi Endüstriyel Sanatlar Eğitim Fakültesi Dergisi, 20, 28-38.

\section{Kaynakça Bilgisi / Citation Information}

Ceyhun Sezgin, A., Ayyıldız, S. ve Efşan Durmaz, N. (2020). Gastronomi ve mutfak sanatları öğrencilerinin gıda etiketlerini okuma düzeyleri. OPUS-Uluslararası Toplum Araştırmaları Dergisi, 16(Özel Sayı), 3321-3343. DOI: 10.26466/opus.750064 